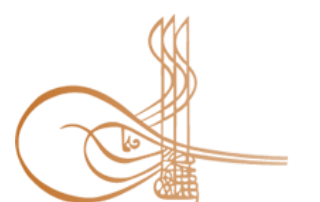

www.turkishstudies.net/economy
Turkish Studies - Economics, Finance, Politics

eISSN: 2667-5625

Research Article / Araștırma Makalesi

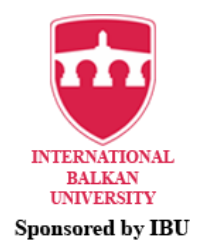

Sponsored by IBU

\title{
Güncel Gelişmeler Işığında Kripto Paraların Kümelenmesi
}

Cluster of Cryptocurrencies in The Light of Current Developments

\author{
Mehmet Yılmaz ${ }^{*}$ Okan Dağ ${ }^{* *}-$ Turan Kocabıyık ${ }^{* * *}$
}

\begin{abstract}
The cryptocurrency market has been in constant growth over the past decade. Cryptocurrencies have a market value of \$ 216 billion and daily trading volumes of \$ 154 billion. Bitcoin takes the lead among 64 cryptocurrencies with a market share of $64 \%$. Although the transaction volume reaches a certain size, market uncertainties cause confusion for investors. It is thought that academic studies should be carried out on this subject in order to eliminate the uncertainties. For this purpose, in this research, cryptocurrencies that have a significant size in the market are clustered according to various criteria. The research was carried out with 17 cryptocurrencies, the largest of which is available, according to market value. The widest date range in which data is available for all cryptocurrencies has been tried to be included in the analysis. In this context, daily data between 02 April 2020 and 20 June 2019 were used. Cryptocurrencies address numbers, market values, prices, returns, supply amount, number of transactions, transaction volume and volatility were used as cluster criteria. In order to perform cluster analysis in WEKA program, the averages of the independent variables in this date range were taken. While performing the analysis, the data was divided into 3 periods as whole data set, before and after corona. Thus, it was observed whether there were any structural changes in the crypto money market during the corona virus period. While performing cluster analysis, Ward, Full Connection and Single Connection techniques, one of the hierarchical clustering algorithms, were used. Considering the results of the study, all algorithms clustered Bitcoin separately from other cryptocurrencies in all periods. A very distinct bitcoin, altcoin distinction is made. Again according to three algorithms; there is no significant difference in cluster results before and after corona virus. In terms of clustering cryptocurrencies, it generally yielded similar results in three algorithms.
\end{abstract}

\footnotetext{
* Doktora Öğrencisi, Süleyman Demirel Üniversitesi, İktisadi ve İdari Bilimler Fakültesi, İşletme Bölümü

PhD Candidate, Suleyman Demirel University, Faculty of Economics and Administrative Sciences, Department of Business Administration

ORCID 0000-0001-8729-3720

mehmet44yilmaz@yahoo.com

** Dr., Süleyman Demirel Üniversitesi, İktisadi ve İdari Bilimler Fakültesi, İşletme Bölümü

Dr., Suleyman Demirel University, Faculty of Economics and Administrative Sciences, Department of Business

Administration

ORCID 0000-0001-9756-722X

okandaq@gmail.com

**** Dr. Öğr. Üyesi, Süleyman Demirel Üniversitesi, İktisadi ve İdari Bilimler Fakültesi, Bankacıllk ve Finans Bölümü

Asst. Prof. Dr., Suleyman Demirel University, Faculty of Economics and Administrative Sciences, Department of Banking and Finance

ORCID 0000-0003-3651-206X

turankocabiyik@sdu.edu.tr
}

Cite as/ Atıf: Yılmaz, M., Dağ, O. \& Kocabıyık, T. (2020). Güncel gelişmeler ışığında kripto paraların kümelenmesi.

Turkish Studies - Economy, 15(3), 1753-1773. https://dx.doi.org/10.47644/TurkishStudies.43592

Received/Gelis: 14 May/Mayıs 2020

Accepted/Kabul: 20 September/Eylül 2020

Checked by plagiarism software

Copyright $(C)$ INTAC LTD, Turkey 
Structured Abstract: The cryptocurrency market has become an indispensable investment tool for all savers in the digital age. There is no need for intense procedures to be an investor in the market. Crypto coins are used as an investment tool rather than a medium of exchange in the world. The cryptocurrency market has been in constant growth over the past decade. Cryptocurrencies have a market value of $\$ 216$ billion and daily trading volumes of $\$ 154$ billion. Bitcoin takes the lead among 64 cryptocurrencies with a market share of $64 \%$. Although the transaction volume reaches a certain size, market uncertainties cause confusion for investors. It is thought that academic studies should be carried out on this subject in order to eliminate the uncertainties. In the study, it is aimed to assist investors in the decision-making process as a result of the clustering of crypto coins with similar criteria. For this purpose, in this research, cryptocurrencies that have a significant size in the market are clustered according to various criteria.

The research was carried out with 17 cryptocurrencies, the largest of which is available, according to market value. The widest date range in which data is available for all cryptocurrencies has been tried to be included in the analysis. In this context, daily data between 02 April 2020 and 20 June 2019 were used. The research data consist of three periods. Pre-Covid-19 period, Covid-19 period and the entire period. Thus, it was observed whether there were any structural changes in the crypto money market during the corona virus period. While performing cluster analysis, Ward, Full Connection and Single Connection techniques, one of the hierarchical clustering algorithms, were used. Cryptocurrencies address numbers, market values, prices, returns, supply amount, number of transactions, transaction volume and volatility were used as cluster criteria. In order to perform cluster analysis in WEKA program, the averages of the independent variables in this date range were taken.

When we look at the analyzes made with the Weka program, Ward and Full Connection Technique, all cryptocurrencies in Cluster 0, Cluster 1 and Cluster 2 are in the same cluster in three different periods. When looking at the analysis results made with a Single Connection Technique; it appears to differ from the other two techniques. According to Ward Technique and Full Connection Technique, it has been observed that the cryptocurrencies before and during Covid-19 have similar features, so the clustering results are the same. In the whole data set of Single Connection Technique, exactly the same clustering was formed with the result obtained with Ward and Full Connection techniques. However, in the period before Covid-19, Crypto.com Coin and Stellar were included in a different cluster. Again, in the Covid-19 period, only Crypto.com Coin was in a different cluster.

\begin{tabular}{|c|c|c|c|}
\hline \multicolumn{4}{|c|}{ Cryptocurrency Cluster Analysis Results According to Ward's Technique } \\
\hline & Entire Period & Pre-Covid-19 Period & Covid-19 Period \\
\hline Cluster 0 & Bitcoin & Bitcoin & Bitcoin \\
\hline \multirow{13}{*}{ Cluster 1} & Ethereum & Ethereum & Ethereum \\
\hline & Tether & Tether & Tether \\
\hline & Bitcoin Cash & Bitcoin Cash & Bitcoin Cash \\
\hline & Bitcoin SV & Bitcoin SV & Bitcoin SV \\
\hline & Litecoin & Litecoin & Litecoin \\
\hline & Binance Coin & Binance Coin & Binance Coin \\
\hline & Tezos & Tezos & Tezos \\
\hline & Unus Sed Leo & Unus Sed Leo & Unus Sed Leo \\
\hline & Cardano & Cardano & Cardano \\
\hline & Chainlink & Chainlink & Chainlink \\
\hline & Huobi Token & Huobi Token & Huobi Token \\
\hline & USD Coin & USD Coin & USD Coin \\
\hline & Dash & Dash & Dash \\
\hline \multirow{3}{*}{ Cluster 2} & XRP & XRP & XRP \\
\hline & Stellar & Stellar & Stellar \\
\hline & Crypto.com Coin & Crypto.com Coin & Crypto.com Coin \\
\hline
\end{tabular}

Turkish Studies - Economy, 15(3) 
Looking at the table, as a result of the clustering process using the Ward Technique, the clusters consisted of the same cryptocurrencies in three time intervals, including entire period, pre-Covid-19 and Covid19 period.

Cryptocurrency Clustering Analysis Results According to Full Connection Technique

\begin{tabular}{|c|c|c|c|}
\hline & Entire Period & Pre-Covid-19 Period & Covid-19 Period \\
\hline Cluster 0 & Bitcoin & Bitcoin & Bitcoin \\
\hline \multirow{13}{*}{ Cluster 1} & Ethereum & Ethereum & Ethereum \\
\hline & Tether & Tether & Tether \\
\hline & Bitcoin Cash & Bitcoin Cash & Bitcoin Cash \\
\hline & Bitcoin SV & Bitcoin SV & Bitcoin SV \\
\hline & Litecoin & Litecoin & Litecoin \\
\hline & Binance Coin & Binance Coin & Binance Coin \\
\hline & Tezos & Tezos & Tezos \\
\hline & Unus Sed Leo & Unus Sed Leo & Unus Sed Leo \\
\hline & Cardano & Cardano & Cardano \\
\hline & Chainlink & Chainlink & Chainlink \\
\hline & Huobi Token & Huobi Token & Huobi Token \\
\hline & USD Coin & USD Coin & USD Coin \\
\hline & Dash & Dash & Dash \\
\hline \multirow{3}{*}{ Cluster 2} & XRP & $\mathrm{XRP}$ & XRP \\
\hline & Stellar & Stellar & Stellar \\
\hline & Crypto.com Coin & Crypto.com Coin & Crypto.com Coin \\
\hline
\end{tabular}

Looking at the table, as a result of the clustering process using the Full Connection Technique, the clusters consisted of the same cryptocurrencies in three time intervals, including entire period, pre-Covid-19 and Covid-19 period. These results are exactly the same as the Ward technique results.

Cryptocurrency Clustering Analysis Results According to Single Connection Technique

\begin{tabular}{cccc}
\hline & Entire Period & Pre-Covid-19 Period & Covid-19 Period \\
\hline Cluster 0 & Bitcoin & Bitcoin & Bitcoin \\
& Ethereum & Ethereum & Ethereum \\
\cline { 2 - 4 } & Tether & Tether & Tether \\
\cline { 2 - 4 } & Bitcoin Cash & Bitcoin Cash & Bitcoin Cash \\
\cline { 2 - 4 } & Bitcoin SV & Bitcoin SV & Bitcoin SV \\
\cline { 2 - 4 } & Litecoin & Litecoin & Litecoin \\
\cline { 2 - 4 } Cluster 1 1 & Binance Coin & Binance Coin \\
\cline { 2 - 4 } & Binance Coin & Tezos & Tezos \\
\cline { 2 - 4 } & Tezos & Unus Sed Leo & Unus Sed Leo \\
\cline { 2 - 4 } & Unus Sed Leo & Cardano & Cardano \\
\cline { 2 - 4 } & Cardano & Chainlink & Chainlink \\
\cline { 2 - 4 } & Chainlink & Huobi Token & Huobi Token \\
\cline { 2 - 4 } & Huobi Token & USD Coin & DSD Coin \\
\cline { 2 - 4 } & USD Coin & Stellar & Dash \\
\cline { 2 - 4 } & Dash & Crypto.com Coin & XRP \\
\hline \multirow{3}{*}{ Cluster 2 } & & XRP & Stellar \\
\cline { 2 - 4 } & & & \\
\cline { 2 - 4 } & XRP & & \\
\cline { 2 - 4 } & Stellar & & \\
\hline
\end{tabular}


Looking at the table, as a result of the clustering process using the Single Connection Technique, Bitcoin is common in Cluster 0 in all three time intervals, including entire period, pre-Covid-19 period and Covid-19 period. Ethereum, Tether, Bitcoin Cash, Bitcoin SV, Litecoin, Binance Coin, Tezos, Unus Sed Leo, Cardano, Chainlink, Huobi Token, USD Coin and Dash are common in Cluster 1, and XRP in Cluster 2.

Considering the results of the study, all algorithms clustered Bitcoin separately from other cryptocurrencies in all periods. A very distinct bitcoin, altcoin distinction is made. Again according to three algorithms; there is no significant difference in cluster results before and after corona virus. In terms of clustering cryptocurrencies, it generally yielded similar results in three algorithms. The fact that similar results emerged as a result of clustering according to the three techniques is one of the important results of this study as an indicator of the applicability of the clustering techniques used in the study. Although Bitcoin is the most important investment tool of the market, other cryptocurrencies have also reached a significant market size. Therefore, these coins should also be recognized, and the complexity of information about the market should be reduced as much as possible. In this respect, it is thought that the study can help investors and those who want to know the market. As a result, cryptocurrencies with similar characteristics are clustered and macro information that can help investors in their decision-making process is presented. According to the results of the research, Bitcoin separated from altcoins and formed a separate cluster. This result is similar to the research of Song et al. (2019).

In this study, cryptocurrencies, which are in the top 17 in terms of market value, were selected as an alternative. In future studies, clustering can be done by increasing the number of alternatives. In addition, hierarchical cluster analysis techniques were used in the analysis part of this study. In other studies, researchers may prefer different techniques.

Keywords: Cryptocurrencies, Cluster Analysis, Ward Linkage, Complete Linkage, Single Linkage

Öz: Kripto para piyasası son on yıllık dönemde sürekli büyüme içerisindedir. Kripto paraların piyasa değeri 216 milyar dolar ve günlük işlem hacimleri 154 milyar dolardır. Sayıları 5 bini geçen kripto paralar içinde \%64'lük piyasa payıyla Bitcoin başı çekmektedir. Her ne kadar işlem hacmi belli bir büyüklüğe ulaşsa da piyasa ile ilgili bilinmezlikler yatırımcılar için kafa karışıklığına neden olmaktadır. Bilinmezliklerin ortadan kaldırılması için bu konuda akademik çalışmalar yapılması gerektiği düşünülmektedir. Bu amaçla, bu araştırmada piyasada önemli büyüklüğe sahip kripto paralar çeşitli kriterlere göre kümelenmiştir. Araştırma piyasa değerine göre en büyük ve verilerine ulaşlabilen 17 kripto para ile gerçekleştirilmiştir. Tüm kripto paralar için verilerin ulaşılabildiği en geniş tarih aralığı analize dahil edilmeye çalışılmıştır. Bu kapsamda 20 Haziran 2019 ile 02 Nisan 2020 tarihleri arasındaki günlük veriler kullanılmıştır. Kümeleme kriteri olarak kripto paraların adres sayıları, piyasa değerleri, fiyatları, getirileri, arz miktarı, işlem sayısı, işlem hacmi ve volatiliteleri kullanılmıştır. WEKA programında kümeleme analizinin gerçekleştirilebilmesi için bağımsız değişenlerin bu tarih aralığındaki ortalamaları alınmıştır. Analiz gerçekleştirilirken veriler tüm veri seti, korona öncesi ve korona sonrası şeklinde 3 döneme ayrılmıştır. Böylece korona virüs döneminde kripto para piyasasında yapısal değişimlerin olup olmadığı gözlemlenmiştir. Kümeleme analizi yapılırken, hiyerarşik kümeleme algoritmalarından Ward, Tam Bağlantı ve Tek Bağlantı teknikleri kullanılmıştır. Çalışmanın sonuçlarına bakıldığında tüm algoritmalar tüm dönemlerde Bitcoin'i diğer kripto paralardan ayrı kümelemiştir. Çok belirgin bir bitcoin, altcoin ayrımı yapılmıştır. Yine üç algoritmaya göre; Korona virüs öncesi ve Korona sonrası dönemlerde kümeleme sonuçlarında önemli bir fark yoktur. Üç algoritmada genel itibarıyla benzer sonuçlar vermiştir.

Anahtar Kelimeler: Kripto Paralar, Kümeleme Analizi, Ward Bağlantı, Tam Bağlantı, Tek Bağlantı

\section{Giriş}

Son on yılda yatırım hayatına yeni bir ürün giriş yapmıştır. Dijital ortamda herhangi bir otoritenin kontrolüne gerek kalmaksızın alınıp satılabilen bu araçlar kripto paralardır. Kripto paralar henüz yatırım yapmasa bile birçok yatırımcı tarafından bilinir hale gelmiştir. Bir yatırım aracı olarak sayıları gün geçtikçe artan kripto paraların kategorilere ayrılması, benzer özellik gösterenlerin sınıflandırılması yatırımcıların kripto paraları tanımaları açısından oldukça önemlidir. Blok zincir 
teknolojisi ve kripto para pazarı oldukça karmaşık bir yapıya sahiptir. Bu piyasa ile ilgili bilgilerin sadeleştirilmesi yatırımcıların karar verme sürecini kolaylaştıracaktır.

Kripto paraların kategorize edilmesi ile ilgili çalışmasıyla Arsov (2018) özellikle altcoinler için bir periyodik cetvel oluşturmaya çalışmıştır. Bunun yanında Osterrieder vd. (2016) kripto paraları daha iyi anlayabilmek için getirileri üzerine istatistiksel bir çalışma ortaya koymuşlardır. Sigaki vd. (2019) kripto paraların verimliliğini çalışırken, Akçalı (2019), Konuşkan vd. (2019), Karaağaç ve Altınırmak (2018) ve Ciaian (2017) kripto paraların birbirleriyle olan fiyat ilişkisini araştırmıştır. Baig vd. (2019) duyarlılık istatistikleri ile bitcoin fiyatı ilişkisini ortaya koymaya çalışırken, Xin vd. (2020) ve Hu vd. (2019) çalışmalarında bitcoin fiyat oluşumlarını daha iyi anlayabilmek için gün içi fiyatları analiz etmişlerdir. Song vd. (2019) Bitcoin-Ethereum filtresi ile kripto para piyasasının yapısal kümeleme analizini gerçekleştirmişlerdir. Urquhart (2017) çalışmasında bitcoin fiyat kümelemesi ile fiyat ve işlem hacmi arasındaki ilişkiye odaklanmıştır. Bu araştırma ile kripto para piyasasının yapısal özellikleri ile ilgili bilgi elde edilecektir. Bu bilgiler de kripto para piyasalarında yatırım yapanların politika geliştirmesine yardımcı olacaktır. Bu konuda yapılan çalışmaların sınırlı sayıda olması literatüre katkı sağlanabileceği düşüncesini ortaya çıkarmıştır.

Araştırmanın takip eden bölümlerinde sırasıyla kripto paralar ile ilgili genel bilgilere, literatür taramasına, analize ve sonuç bölümüne yer verilecektir.

\section{Kripto Paralar}

Kripto paralar, para birimi oluşturmak ve dağıtmak için kriptografinin kullanıldığı eşler arası bir dijital değişim sistemidir. Bu para birimi, standart bir para birimi gibi çalışan ve kullanıcıların merkezi bir güvenilir otoriteye ihtiyaç duymadan mallar ve hizmetler için sanal ödeme yapma imkanı sağlayan sanal bir para sistemidir (Farell, 2015: 4). Kripto para ile ilgili literatürde birçok farklı tanımlamalar yapılmakla birlikte, Avrupa Merkez Bankasına (2012) göre, düzenleyiciler tarafindan denetlenen ve genellikle kontrol edilen ve belirli bir sanal topluluğun üyeleri arasında kullanılan ve kabul edilen düzensiz bir para türü olarak tanımlanmıştır.

Kripto paraların ilki ve en popüleri olan Bitcoin'in ortaya çıkmasından günümüze kadar birçok kripto para piyasaya çıkmıştır. Nisan 2020 itibarıyla pazarda 5400'e yakın kripto para bulunmaktadır. Bu paralar 21 bin 609 borsada işlem görmektedir. Kripto paraların ulaştı̆̆ piyasa değeri 216 milyar USD'dir ve piyasada günlük gerçekleşen işlem hacmi 154 milyar USD'dir. İşlem hacminden de anlaşılacağı gibi piyasada paralar önemli ölçüde ilgi görmektedir. Kripto para piyasasında piyasa değerinin \%64'ü Bitcoin'e aittir. Bununla birlikte, mevcut 5400'e yakın kripto para içinden sadece 15 'inin piyasa değeri bir milyar doların üzerinde piyasa değerine sahiptir (CoinMarketCap, 2020). Kripto paralar borsa adı verilen platformlar üzerinden alınıp satılmaktadır. Binance, BKEX, MXC Fatbtc, Bilaxy, Coinsbit, Hotbit, BitForex, P2PB2B ve CoinBene 30 günlük işlem hacmine göre en büyük borsalardır (CoinMerketCap, 2020). Piyasa değerine göre en büyük kripto paralar Tablo 1' de sıralanmıştır. 
Tablo 1: Piyasa Değerine Göre En Büyük Kripto Paralar

\begin{tabular}{|c|c|c|c|c|c|}
\hline $\begin{array}{l}\text { Sira } \\
\text { No }\end{array}$ & İsim & $\begin{array}{l}\text { Piyasa Değeri } \\
\text { (USD) }\end{array}$ & $\begin{array}{l}\text { Fiyat } \\
\text { (USD) }\end{array}$ & $\begin{array}{l}\text { Günlük İslem } \\
\text { Hacmi (USD) }\end{array}$ & $\begin{array}{c}\text { Dolaşımdaki Miktar } \\
\text { (Adet) }\end{array}$ \\
\hline 1 & Bitcoin & 140.102 .929 .131 & $7.636,28$ & 32.217 .076 .816 & 18.347.012 BTC \\
\hline 2 & Ethereum & 21.745 .610 .624 & 196,47 & 17.755 .184 .568 & 110.682.594 ETH \\
\hline 3 & XRP & 8.621 .222 .216 & 0,20 & 1.645 .759 .431 & $44.089 .620 .959 \mathrm{XRP} *$ \\
\hline 4 & Tether & 6.376 .577 .878 & 1,00 & 44.768 .333 .717 & 6.361.032.509 USDT * \\
\hline 5 & Bitcoin Cash & 4.502 .641 .862 & 244,83 & 3.477 .720 .898 & $18.390 .925 \mathrm{BCH}$ \\
\hline 6 & Bitcoin SV & 3.598 .936 .652 & 195,70 & 1.867.275.099 & 18.389.671 BSV \\
\hline 7 & Litecoin & 2.879 .993 .192 & 44,58 & 4.651 .996 .353 & 64.597.568 LTC \\
\hline 8 & $\begin{array}{l}\text { Binance } \\
\text { Coin }\end{array}$ & 2.533.071.505 & 16,29 & 400.022 .876 & 155.536.713 BNB * \\
\hline 9 & EOS & 2.508 .801 .550 & 2,72 & 3.247 .117 .255 & $922.124 .316 \mathrm{EOS} *$ \\
\hline 10 & Tezos & 1.961 .159 .199 & 2,77 & 268.126 .177 & 708.369.475 XTZ * \\
\hline
\end{tabular}

Kaynak: https://coinmarketcap.com/, 27.04.2020.

Kripto para piyasasının \%64'ü Bitcoin'e aittir. Dolayısıyla Bitcoin ile ilgili bir pencere açmamız gerekirse; Bitcoin 2008 yılında ortaya çıkmış dijital bir paradır. Kripto para piyasasının ilk ve en popüler ürünü Bitcoin’ dir. Sayıları 5 bini geçen, Bitcoin dışındaki diğer kripto paralara altcoin denilmektedir. $\mathrm{Bu}$ paralar merkezi bir otorite tarafından kontrol edilmez ve çoğu blok zincir teknolojisi ile alınır satılır. Geldiğimiz noktada Bitcoin değişim aracından daha çok bir yatırım aracı olarak görülmektedir. Oldukça yüksek volatiliteye sahip Bitcoin dışarıdan gelecek manipülasyonlara karş1 şifreleme ve mutabakat sistemleriyle korunmaktadır. Şu an piyasada 18 milyon adetten fazla Bitcoin bulunmakla birlikte, maksimum Bitcoin arzı 21 milyon adet olacaktır (Usta \& Doğantekin, 2018, 48). Yıllar itibarıyla Bitcoin fiyat grafiği Şekil 1'de sunulmuştur.

Şekil 1: Yıllar İtibarıyla Bitcoin Fiyatı (USD)

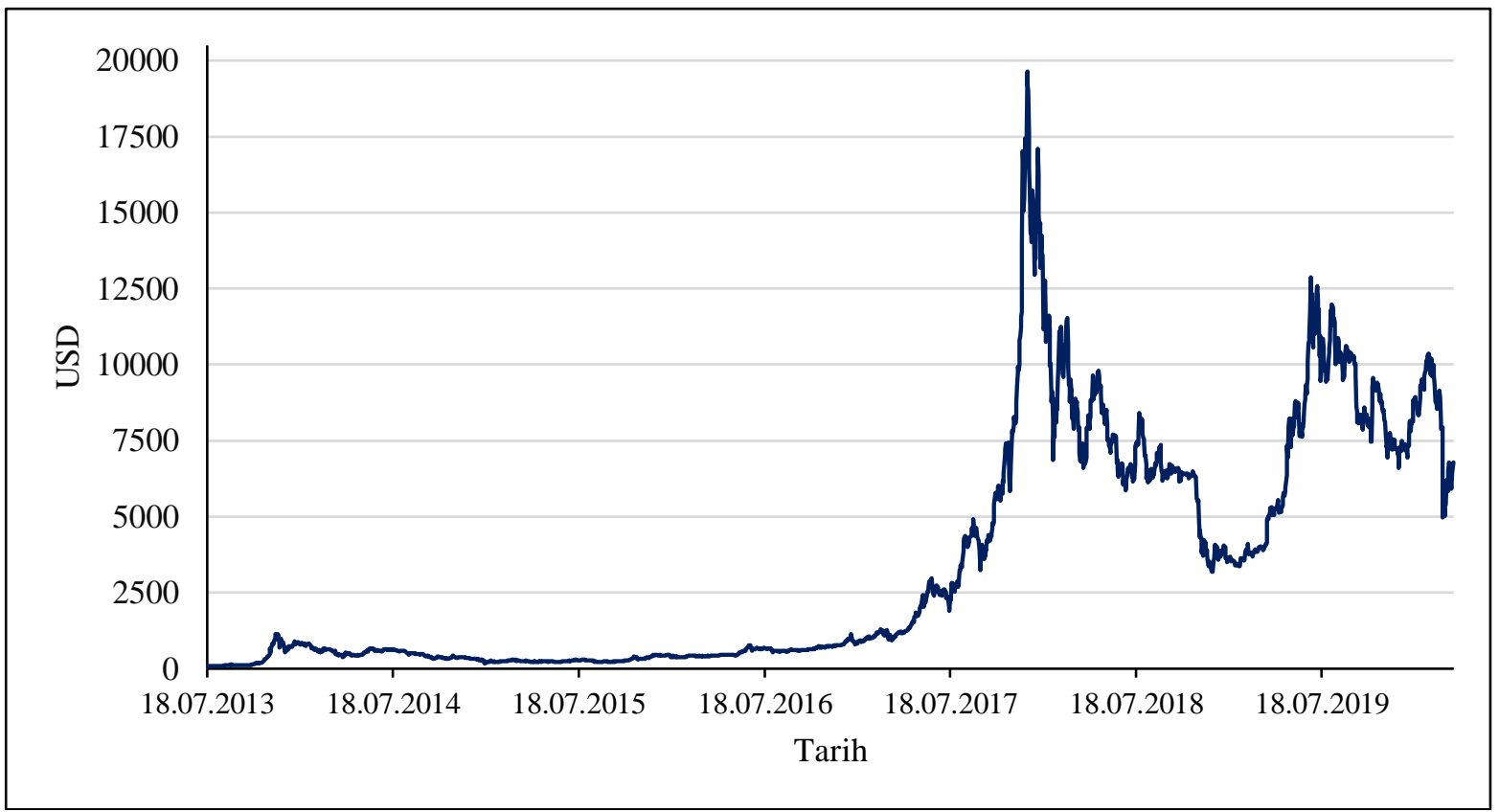

Kaynak: https://coinmetrics.io/community-network-data/, 26.04.2020.

Bitcoin en çok bilinen ve tanınan kripto paradır. Alım satımı dijital cüzdan ile gerçekleştirilir. Bitcoin bir kripto para olmakla birlikte gelecekte finans alanında çok geniş bir uygulama alanına 
sahip olacağ tahmin edilen blok zincir teknolojisinin hayata geçirilmesinde önemli bir yere sahiptir. Bitcoin ve diğer kripto paralarda meydana gelen işlem hacmi sisteme olan güveni göstermektedir (Usta \& Doğantekin, 2018, 8-40).

\section{Literatür Taraması}

Bu bölümde kripto paralar ve kümeleme analizlerine yönelik geçmişte yapılmış çalışmalara yer verilecektir. Literatürde taraması üç grupta ele alınacaktır. İlk olarak kripto paraların kümeleme çalışmalarına yönelik literatüre yer verilecek, ardından kripto paraların birbiriyle ilişkilerini keşfetmeye yönelik çalışmalara ve son olarak da kümeleme çalışmalarına yer verilecektir.

\section{- $\quad$ Kripto Paralar İle İlgili Kümeleme Çalışmalart}

Xin, Shenghong ve Chong tarafından 2020 yılında yapılan bu çalışmada Bitcoin pazarındaki fiyat kümelenmesi amaçlanmıştır. Yapılan bu çalışmada çeşitli zaman dilimlerinin gün içi verileri analiz sırasında kullanılmıştır. Yapılan analiz sonucunda yüksek ve düşük fiyatlar için kümelenme sonuçları ortaya konmuştur (Xin, Shenghong ve Chong, 2020).

Song, Chang ve Song tarafından 2019 yılında yapılan bu çalışmada kripto para piyasasının yapısı, toplayıcı hiyerarşik kümeleme algoritmaları ile analiz edilmeye çalışılmıştır. Yapılan bu çalışmada Bitcoin-Ethereum filtreleme adı verilen bir filtreleme kullanılarak diğer kripto paralarla olan ilişkileri analiz edilmiştir. Sonuç olarak, Bitcoin ve Ethereum'un pazardaki liderliği ve nispeten daha az işlem gören kripto para birimlerinden oluşan altı homojen küme ortaya konmuştur (Song, Chan \& Song, 2019).

Baig, Blau ve Sabah tarafından 2019 yılında yapılan bu çalışma, Bitcoin seviyesi ve pazar çapında duyarlılı̆̆ın çeşitli ölçümlerini kullanarak olağandışı Bitcoin fiyat kümelenmesini açıklamayı amaçlamaktadır. Yapılan analizin sonucunda duyguların fiyat kümelenmesi ile güçlü bir pozitif ilişkiye sahip olduğunu göstermektedir. Ekonomik açıdan, Google Eğilimler tarafindan ölçülen bir standart sapma artışı, Bitcoin'deki olağandışı fiyat kümelenmesinin \% 2.5 ila \% 5 'ini açıklamaktadır. Ayrıca, yatırımcı hissiyatının diğer ölçümleri kullanıldığında sonuçların sağlam olduğu da görülmektedir (Baig, Blau \& Sabah, 2019).

$\mathrm{Hu}$ ve arkadaşları 2019 yılında yaptıkları çalışmada, kripto para birimlerinin gün içi fiyat davranışlarını incelemiştir. Çalışmada veri seti olarak, Bitcoin (BTC), litecoin (LTC) ve ripple (XRP) kullanılmıştır. Döviz kurları ve örnek dönemler olarak ise, LTC/BTC (6/16/2017-2/28/2018), XRP/BTC (2/10/2017-2/28/2018), BTC/USD (8/17/2011-2/28/2018) ve BTC/EUR (4/16/20162/28/2018) dönemleri kullanılmıştır. Çalışmada, işlem düzeyinde fiyatların psikolojik olarak çekici sayılar ( 0 ve 5 gibi tamsayılar) yerine, müzakereler ve stratejik ticaret nedeniyle oluştuğu sonucuna varılmıştır. Ayrıca 00 ile biten fiyatların 1 kademe altında ve 1 kademe üstünde çokça değişkene rastlanmıştır (Hu vd., 2019).

Sigaki, Perc ve Ribeiro 2019 yılında yaptıkları çalışmada, kripto paraların piyasa değeri ve fiyat açısından kümelenmesini araştırmışlardır. Çalışmada veri olarak, 437 kripto para biriminin günlük kapanış fiyatları ve piyasa değeri kullanılmıştır. Çalışmanın sonucunda kripto para birimleri dört kümeden oluşmuştur. Elde edilen kümelerde yer alan genç kripto para birimlerinin, kendilerinden daha önce çıkan para birimlerinin fiyat ve piyasa değeri açısından benzer eğilim gösterdiği ortaya çıkmıştır. Ayrıca dijital para birimlerinin gelecekte de piyasa değeri açısından etkinliğinin devam edeceği varsayılmaktadır (Sigaki, Perc \& Ribeiro, 2019).

Urquhart 2017 yılında yaptı̆̆ çalışmada, Bitcoin'de fiyat kümelenmesini incelemiştir. Burada ondalık sayıların önemi dikkate alınmıştır. Çalışmada veri seti olarak, 1 Mayıs 2012 ile 30 Nisan 2017 tarihleri arasındaki Bitcoin'in günlük kapanış fiyatları kullanılarak kümeleme yapılmıştır. Çalışmada veri olarak kullanılan fiyatların \%10'undan fazlası 00 ondalık hane ile biten 
fiyatların kümelenmesine ilişkin bulgudur. Ayrıca fiyat ve hacmin fiyat kümelenmesi ile pozitif yönde anlamlı bir ilişkisi olduğu ortaya çıkmıştır (Urquhart, 2017).

\section{Kripto Paraların Birbirileri İle İlişkilerini Keşfetmeye Yönelik Çalışmalar}

Bouri, Shahzad ve Roubaud 2019 yılında yaptıkları çalışmada, en fazla piyasa değerine sahip olan yedi kripto para biriminde yaşanan fiyat patlamasını tarihsel olarak belirlemeyi amaçlamışlardır. Çalışmada veri seti olarak, 7 Ağustos 2015'ten 31 Aralık 2017'ye kadar bu kripto para birimlerin günlük fiyatları kullanılmıştır. Araştırmacılar GSADF tekniğini uygulayarak birden fazla patlama dönemine ilişkin kanıtlar ortaya koymuştur. Çalışmada özellikle Bitcoin'in daha uzun süreli patlamaya maruz kaldığı bulunmuştur. Ayrıca bir kripto para biriminde yaşanacak fiyat açısından patlayıcı olma olasılığının, diğer kripto para birimlerinde yaşanabilecek patlama olasıllı̆ıını önemli ölçüde arttırdığı bulgulanmıştır (Bouri, Shahzad \& Roubaud, 2019).

Konuşkan vd., 2019 yılında kripto paralardan Bitcoin, Ethereum ve Ripple arasında kısa veya uzun dönemli bir ilişkinin olup olmadığını araştırmışlardır. Araştırmada veri olarak 01.01.201831.12.2018 tarihleri arasındaki Bitcoin, Ethereum ve Ripple kapanış fiyatları kullanılmıştır. Bitcoin'i bağımlı değişken, Ethereum ve Ripple ise bağımsız değişken olarak çalışmaya dahil edilmiştir. Çalışmada birim kök testi ve Johansen Eşbütünleşme testi kullanılmıştır. Son olarak vektör hata düzeltme modeli ile üç kripto para arasındaki ilişkinin analizi sonucunda bu kripto paralar arasında kısa dönem ilişkinin olduğu ortaya çıkmıştır (Konuşkan vd., 2019).

Adjepong ve Alagidede 2019 yılında, 8 Ağustos 2014 ile 2 Şubat 2018 tarihlerini kapsayan veri seti ile en fazla piyasa değerine sahip olan yedi kripto para biriminin piyasa tutarlılıklarının ve oynaklıklarının nedensel bağlantılarını araştırmıştır. Varlıkların oynaklık yayılmalarının yönünü araştırmak için parametrik ve parametrik olmayan testler kullanmışlardır. Çalışmanın sonuçlarına göre, belirli piyasa çiftleri ve ayrıca yedi kripto paranın tümüne sahip olan yatırım sepeti için hafta içi ile aylık ölçekler arasında bir sınırlılığın olduğu tespit edilmiş. Ayrıca bağlantılılık ve volatilite nedensel bağlantılarının seviyesinin, piyasadaki ticari verilere ve volatiliteye karşı duyarlı olduğunu ortaya koymuşlardır (Adjepong \& Alagidede, 2019).

Akçalı ve Şişmanoğlu 2019 yılında yaptıkları çalışmada, piyasa değeri en fazla olan on beş kripto paranın birbirleri ile arasındaki ilişkiyi incelemişlerdir. Çalışma kapsamında kripto paraların 07.08.2015-21.11.2018 tarih aralığındaki dolar cinsinden günlük kapanış fiyatları kullanılmıştır. Bu paralar arasındaki ilişkiyi Toda-Yamamoto Nedensellik Testi ile analiz etmişlerdir. Analiz sonucunda her bir kripto paranın genel olarak tek yönlü ya da çift yönlü birbirini etkilediği ortaya çıkmıştır (Akçalı \& Şişmanoğlu, 2019).

Karaağaç ve Altınırmak 2018 yılında kripto paralar içerisinde en fazla piyasa değerine sahip on paranın birbirleriyle etkileşimini analiz etmişlerdir. Çalışmada kripto paraların 15 Aralık 2017 ve 17 Ocak 2018 tarihleri arasındaki günlük fiyatları kullanılmıştır. Bu fiyatlar arasındaki ilişkiyi incelemek amacıyla Johansen Eşbütünleşme Testi ve Granger Nedensellik Testi kullanılmıştır. Çalışmanın sonucunda, kripto paraların fiyat hareketlerinin kısa dönemde birbirini etkilediği tespit edilmiştir (Karaağaç \& Altınırmak, 2018).

Ciaian, Rajcaniova ve Kancsa 2018 yılında yaptıkları çalışmada kısa ve uzun vadede Bitcoin ve altcoin piyasaları arasındaki bağımlılıkları incelemişlerdir. Çalışmada 2013-2016 dönemi için 17 kripto para biriminin (Bitcoin ve 16 alternatif kripto para birimi) ve iki altcoin fiyat endeksinin günlük verilerine dayanarak zaman serisi analizi yapmışlardır. Araştırmanın sonucunda, Bitcoin ve altcoin pazarlarının birbirine bağımlı olduğunu ortaya çıkmıştır. Ayrıca Bitcoin-altcoin fiyat ilişkisinin, kısa vadeden ziyade uzun vadede daha güçlü olduğu ve uzun vadede makro finansal göstergelerin altcoin fiyat oluşumunda, Bitcoin'den biraz daha fazla etkili olduğu tespit edilmiştir (Ciaian, Rajcaniova \& Kancsa, 2018).

Turkish Studies - Economy, 15(3) 
Osterrieder, Lorenz ve Strika 2016 y1lında altı kripto para biriminin istatistiksel benzerliklerini ve fiyat açısından davranışlarını araştırmışlardır. Quandl.com adresindeki BNC2 veri tabanından kripto para birimleri için geçmiş küresel fiyat endekslerini kullanmışlardır. Çalışmada, Haziran 2014 - Eylül 2016 dönemi günlük verileri kullanılmıştır. Araştırmanın sonucunda, kripto para birimlerinden aynı temel teknolojiyi kullanan kripto paraların benzer istatistiksel özellikler sergilediği bulgulanmıştır (Osterrieder, Lorenz \& Strika, 2016).

\section{- $\quad$ Kümeleme Çalışmaları}

Baig ve Sabah tarafindan 2019 yılında yapılan bu çalışmada açığa satış faaliyetlerinin hisse senedi piyasalarında fiyat kümelenmesi düzeyindeki rolü incelenmektedir. Mevcut veriler aylık ve günlük şekilde ele alınarak analiz edilmiştir. Sonuçlar hem gün içi hem de kapanış hisse senedi fiyatlarının daha homojen dağılma eğiliminde olduğunu ve bu nedenle kısa vadeli satıcıların varlığının bilgi açısından verimli olduğunu göstermektedir (Baig \& Sabah, 2019).

Tekin tarafindan 2018 yılında yapılan bu çalışmada, Borsa İstanbul'da işlem gören hisse senetlerinden etkin bir portföy oluşturulması ve portföy oluşturulmasında kümeleme analizinin kullanılabilirliğinin sınanması amaçlanmıştır. Kümeleme analizi yapılırken finansal tablolardan ve hisse senedi fiyat hareketlerinden yola çıkılmıştır. Çalışmada kümeleme analizi tekniklerinden Ward, K-Ortalamalar ve İki Aşamalı kümeleme yöntemleri kullanılmıştır. Yapılan analiz sonucunda üç teknikten elde edilen sonuçlar, benzerlik göstermiştir (Tekin, 2018).

Mishra ve Tripathy tarafindan 2018 yılında yapılan bu araştırmada, Hindistan Ulusal Borsası'nın tamamen bilgisayarlı ticaret sisteminde yürütülen bireysel işlemlerde fiyat ve ticaret büyüklüğünün kümelenmesi incelenmiştir. Ayrıca Hindistan Ulusal Borsası'nda işlem gören hisse senetleri için gün içi getiri ve likidite modelleri de incelenmektedir. İşlem gören hisse senetleri için büyüklük ve fiyat kümelenmesi olduğuna dair güçlü kanıtlar bulunmaktadır. Sonuç olarak tüm örneklem için fiyat kümelenmesi ile ticaret fiyatı ondalıkları arasında azalan bir ilişki gözlenmektedir. İşlem hacmi ve piyasa değerinin kontrol edilmesinin ardından sonuçların tutarlı olduğu görülmektedir (Mishra \& Tripathy, 2018).

2018 y1lında Gazel ve Akel tarafindan yapılan çalışmada Borsa İstanbul'da farklı sektör endeksleri içerisinde yer alan hisse senetlerinin geçmiş fiyat verilerine göre kümelenmesi amaçlanmıştır. Yapılan bu çalışmada çeşitli sektörlerde yer alan 70 farklı hisse senedinin 2012-2015 dönemine ait haftalık verilerinden yararlanılmıştır. Ele alınan bu hisse senetleri hiyerarşik kümeleme analizi teknikleri ile incelenmiştir. Yapılan analiz sonucunda Ward tekniğinin diğer bağlantı tekniklerinden daha iyi neticeler ortaya koyduğu görülmüştür (Gazel \& Akel, 2018).

Yapılan bir diğer çalışmada Arı, Özköse, Doğan ve Calp tarafından 2016 yılında Borsa İstanbul'da işlem gören 90 adet firmanın finansal performanslarının değerlendirilmesi amaçlanmıştır. Yapılan bu çalışmada 2013 yılına ait finansal oranlardan yararlanılmıştır. Çalışmada veri madenciliği tekniklerinden olan İki Aşamalı Kümeleme Analizi kullanılarak şirketler kümelenmiştir. Yapılan analiz neticesinde küme kalitesi yüksek iki küme elde edilmiştir (Arı, Özköse, Doğan \& Calp, 2016).

Blau ve Griffith tarafından 2016 yılında gerçekleştirilen çalışmada, fiyat oluşumundaki sürtünmelerin hisse senedi fiyatlarının istikrarını nasıl etkilediği incelenerek oynaklığın belirleyicilerini belirlemek için kümeleme analizinden yararlanılmıştır. Özellikle, yuvarlak fiyatlama artışları üzerinde kümelenmenin daha oynak finansal piyasalara yol açacağı hipotezi test edilmiştir. Yapılan analizler sonucunda çok değişkenli testler, fiyat kümelenmesi ile hisse senedi fiyat oynaklığı arasında güçlü ve pozitif bir ilişkiyi doğrulamaktadır (Blau \& Griffith, 2016).

2016 yılında Çalış ve Baynal tarafından yapılan çalışmada kümeleme analizi ile bankacılık sektöründe satış stratejilerinin belirlenmesi amaçlanmıştır. Yapılan bu çalışmada Türkiye'de faaliyet 
gösteren bir banka şubesine ait 200 müşterinin 12 farklı değişken göz önünde bulundurularak müşteri profillerine göre satış stratejilerinin geliştirilmesi amaçlanmıştır. Çalışma sırasında K-Ortalamalar tekniğinden yararlanılmıştır. Çalışmanın sonucunda elde edilen sonuçlar analiz edilerek kümelere ayrılan müşterilerle ilgili stratejiler ortaya konmuştur (Çalış \& Baynal, 2016).

Kalfa ve Bekçioğlu 2013 yılında yaptıkları çalışmada İMKB 100 endeksi kapsamında yer alan 42 şirketin finansal oranlar yardımıyla kümelenmesini amaçlamıştır. Çalışmada 10 finansal orandan yararlanılmıştır. Kümeleme analizinin ardından diskriminant analizi ile şirketlerin doğru bir şekilde gruplandırılıp gruplandırılamadığı test edilmiştir ve yapılan diskriminant analizi sonucunda şirketlerin doğru bir şekilde kümelere ayrıldığı sonucuna ulaşılmıştır (Kalfa \& Bekçioğlu, 2013).

Karabayır ve Doğanay tarafından 2010 yılında yapılan çalışmada İMKB-100 endeksi kapsamında işlem gören hisse senetlerinin risk-getiri ölçütlerine göre sınıflandırılması amaçlanmıştır. Yapılan kümeleme analizi neticesinde hisse senetleri 10 kümeye ayrılmış, elde edilen bulgulara göre yatırımcının ilk zaman aralığında seçtiği hisse senetlerinden oluşan kümeyi, ikinci zaman aralığında portföyünde tuttuğunda kazanç sağlayacağı sonucuna ulaşılmıştır (Karabayır \& Doğanay, 2010).

\section{Araştırma}

$\mathrm{Bu}$ çalışmada kripto paraların güncel gelişmeler 1şığında kümelenmesi amaçlanmıştır. Analiz ile ilgili bu bölümde öncelikle veri seti ile ilgili bilgiler sunulacaktır. Ardından metodoloji ve bulgulara yer verilecektir.

\section{Veri Seti}

Araştırmada piyasa değeri açısından en büyük 20 kripto para analize dahil edilmek istenmiştir. Fakat 3 kripto paranın bağımsız değişkenlere ait verilerine ulaşılamadığı için 17 para analize dahil edilmiştir. Veriler CoinMetrics sitesinden indirilmiştir (CoinMetrics, 2020). Ayrıca tüm kripto paralar için verilerin ulaşılabildiği en geniş tarih aralığı analize dahil edilmeye çalışılmıştır. Bu kapsamda 02 Nisan 2020 ile 20 Haziran 2019 tarihleri arasındaki günlük veriler kullanılmıştır. WEKA programında kümeleme analizinin gerçekleştirilebilmesi için bağımsız değişkenlerin bu tarih aralığındaki ortalamaları alınmıştır. Analiz gerçekleştirilirken veriler tüm veri seti, Covid-19 öncesi ve Covid-19 sonrası şeklinde 3 döneme ayrılmıştır. Covid-19 sonrası dönem Çin'de virüs nedeni ile ilk ölümün gerçekleştiği tarihten yani 11 Ocak 2020'den başlatılmıştır (New York Times, 2020). Araştırmaya dahil edilen kripto paraların listesi ve değişken kodları Tablo 2'de gösterilmiştir. 
Tablo 2: Araştırmaya Dahil Edilen Kripto Paralar

\begin{tabular}{|c|c|c|}
\hline $\begin{array}{c}\text { Sura } \\
\text { No }\end{array}$ & Değişken Adı & Değişken Kodu \\
\hline 1 & Bitcoin & BTC \\
\hline 2 & Ethereum & ETH \\
\hline 3 & XRP & XRP \\
\hline 4 & Tether & USDT \\
\hline 5 & Bitcoin Cash & BCH \\
\hline 6 & Bitcoin SV & BSV \\
\hline 7 & Litecoin & LTC \\
\hline 8 & Binance Coin & BNB-Mainnet \\
\hline 9 & Tezos & XTZ \\
\hline 10 & Unus Sed Leo & LEO-EOS \\
\hline 11 & Stellar & XLM \\
\hline 12 & Cardano & ADA \\
\hline 13 & Chainlink & LINK \\
\hline 14 & Huobi Token & HT \\
\hline 15 & USD Coin & USDC \\
\hline 16 & Crypto.com Coin & CRO \\
\hline 17 & Dash & DASH \\
\hline
\end{tabular}

Kaynak: https://coinmetrics.io/, 05.04.2020

Araştırmaya dahil edilen bağımsız değişkenler Tablo 3'te gösterilmiştir. Toplam 8 bağımsız değişken ile analiz gerçekleştirilmiştir.

Tablo 3: Araştırmada Kullanılan Bağımsız Değişkenler

\begin{tabular}{|c|c|c|}
\hline $\begin{array}{l}\text { Sira } \\
\text { No }\end{array}$ & Değiş̧ken Adı & Açıklaması \\
\hline 1 & AdrActCnt & Ağda etkin olan benzersiz adreslerin toplam sayısıdır. \\
\hline 2 & CapMrktCurUSD & $\begin{array}{l}\text { Mevcut arzın toplam USD değeridir Ağ değeri veya piyasa değeri olarak } \\
\text { da adlandırılır. }\end{array}$ \\
\hline 3 & PriceUSD & $\begin{array}{l}\text { USD bazında gün sonu kapanış değeridir. GMT'ye (Greenwich Mean } \\
\text { Time) göre gece yarısı } 00.00 \text { verisidir. }\end{array}$ \\
\hline 4 & ROI30d & 30 gün önce satın alma işlemi gerçekleștiren varlığın yatırım getirisidir. \\
\hline 5 & SplyCur & $\begin{array}{l}\text { Söz konusu aralıkta defterde şimdiye kadar oluşturulmuş (arz edilmiş) ve } \\
\text { görülebilir tüm yerel birimlerin toplamı. Hesap tabanlı protokoller için, } \\
\text { yalnızca pozitif bakiyesi olan hesaplar sayılır. }\end{array}$ \\
\hline 6 & TxCnt & Bir günde gerçekleşen işlem sayısıdır. \\
\hline 7 & TxTfrValAdjUSD & $\begin{array}{l}\text { Bir günde adresler arasında aktarılan yerel birimlerin toplamının USD } \\
\text { değeridir }\end{array}$ \\
\hline 8 & VtyDayRet30d & $\begin{array}{l}\text { Son } 30 \text { günün volatilitesidir. Getirilerin doğal logaritmalarının standart } \\
\text { sapmasıdır. }\end{array}$ \\
\hline
\end{tabular}

Kaynak: https://coinmetrics.io/, 05.04.2020

\section{Metodoloji}

Çalışmanın bu bölümünde, bu araştırmada da kullanılan, veri madenciliği tekniklerinden biri olan Kümeleme Analizi ve Hiyerarşik Kümeleme algoritmalarından Ward, Tam Bağlantı ve Tek Bağlantı teknikleri açıklanacaktır.

\section{Kümeleme Analizi}

Veri Madenciliği genel bir şekilde tanımlandığında; devasa boyuttaki veri içerisinden, ham halde bulunan, değerli, verilerin ortaya çıkarılması süreci olarak söylenebilmektedir. Veri madenciliği incelendiği zaman günümüze kadar pek gün yüzüne çıkmamış bir süreç gibi 
algılanırken; aslında 1990'lı yıllardan itibaren yaşantının içerisinde yer aldığ 1 ortaya konmaktadır. Veri madenciliğinin ana mantığının klasik istatistik teknikler olduğu bilinse de başka bir istatistiki yöntemi veri madenciliği şeklinde tanımlamak doğru bir ifade değildir. Bununla beraber veri madenciliği istatistiki yöntemlerin evrim geçirmiş şekli olsa da, kendisine has özellikleri bulunmaktadır (Koyuncugil \& Özgülbaş, 2006: 4).

Veri madenciliği sürecinde yararlanılan teknikler; tanımlayıcı ve tahmin edici teknikler olarak iki temel başlık altında toplanmaktadır. Veri madenciliği teknikleri yerine getirdikleri fonksiyonlara bakılarak; sinıflama ve regresyon teknikleri, birliktelik kuralları ve kümeleme teknikleri olarak üç temel başlık altında toplanmaktadır. Sınıflama ve regresyon teknikleri tahmin edici, birliktelik kuralları ve kümeleme teknikleri tanımlayıcı modeller olarak ifade edilmektedir (Albayrak \& Y1lmaz, 2009: 33).

Veri madenciliği tekniklerinden olan kümeleme analizi, verileri kendi içlerinde nispeten homojen ve birbirleri arasında nispeten heterojen olan gruplara ayıran bir gruplama tekniğidir. Kümeleme analizi; birkaç aşamadan meydana gelen bir çözüm süreci olarak tanımlanmaktadır. Analizin ilk aşamasında veri girişi yapılmaktadır. Bir başka deyişle başlangıçta doğal sınıflamalarıyla ilgili net verilerin olmadığı ana kütlelerden seçilen $n$ sayıda birimin analiz edilen $\mathrm{p}$ sayıda değişkene ait gözlem netice verileri elde edilmektedir. Bu sayede veri matrisi meydana getirilmiş olmaktadır. Bir sonraki aşamada verilerin ölçüm şekline yaraşır bir benzerlik ölçüsüyle elemanların uzaklıklar matrisi elde edilmektedir. Daha sonra en uygun kümeleme algoritması tercih edilmektedir ve ardından uygulama aşamasına geçilmektedir. Algoritmanın uygulanması neticesinde elemanlar kümelere bölünmüş olmaktadır. Kümeleme analizi neticelerinin anlamlı olup olmadığının değerlendirildiği adım ise kümeleme analizinin en son aşamasıdır. Kümeleme analizi neticesinde kümeleri meydana getiren nesneler birbirine benzerlik gösterirken, diğer kümelerin nesnelerinden farkl1l1k göstermektedirler. Kümeleme analizinin iyi sonuçlar vermesi durumunda, bir geometrik şekil içerisinde nesneler küme içerisinde birbirlerine olabildiğince yakın durumda bulunurken; kümeler ise başka kümelerden olabildiği kadar uzak durumda yer almaktadır (Vatansever, 2008: 84).

Kümeleme yöntemleri; uzaklık ölçülerinden yararlanarak nesneleri küme içerisinde homojen ve kümeler arasında heterojen kümeler meydana getirmeye olanak tanımaktadır. Kümeleme analizinde pek çok algoritma bulunmaktadır. Fakat literatürde genel olarak algoritmalar iki esas başlık altında incelenmektedir. Bu başlıklar, hiyerarşik kümeleme teknikleri ve hiyerarşik olmayan kümeleme teknikleri şeklinde adlandırılmaktadır (Ketchen \& Shook, 1996: 444). Hem hiyerarşik kümeleme tekniklerinde hem de hiyerarşik olmayan kümeleme tekniklerinde asıl maksat, bir kümenin diğer kümelerle arasında bulunan farklılıkları ve kümelerin içerisinde yer alan nesnelerin birbirleri ile olan benzerliklerini en üst seviyeye çıkarmaktır. Bir başka ifade ile küme içi homojenlik maksimum seviyeye çıkarılırken; kümeler arası homojenlik ise minimum hale getirilmektedir (Akın, 2008: 8).

\section{Hiyerarşik Kümeleme Analizi}

Hiyerarşik Kümeleme Analizi, nesneyi nesne ile ilişkilendiren (toplayıcı) veya ayıran (ayrıştırıcı) bir teknik olarak ifade edilmektedir. Aynı zamanda nesnelerin temeldeki yapısını bulmak için kullanılan ve tüm nesneler işlendiğinde durdurulan yinelemeli bir tekniktir (Steinbach, Ertöz \& Kumar, 2003: 8-9).

Toplayıcı yöntemler, her bir nesne ile ayrı bir kümede başlamaktadır. Daha sonra bu yöntem kümeleri sırayla birleştirerek, tüm nesneler tek bir kümeye ait oluncaya kadar her adımdaki kümelerin sayısını azaltmaktadır. Bir başka ifadeyle tümevarım şeklinde adımları izlemektedir. Ayrıştırıcı yöntemler ise toplayıcı yöntemlerin aksine tümden gelim esasına dayanmaktadır. Ayrıştırıcı yöntemler bir kümedeki tüm nesnelerle başlamaktadır ve daha sonra küme başına bir nesne olana kadar daha küçük kümelere bölünmeye devam etmektedir (Downs \& Barnard, 2002: 4). 
Hiyerarşik Kümeleme algoritmasında bir yöntemi tanımlarken iki önemli seçenek vardır. Bunlar; nesneler veya gruplar arasındaki benzerlik ölçüsü tipi ve bağlantı tekniğidir. İlk olarak, benzerlik matrisi oluşturularak nesneler arasındaki benzerlik için sayısal bir değer belirlenmektedir. Nesneler arasındaki benzerliği belirlemenin birçok yolu bulunmaktadır. Ancak genellikle en popüler olan Öklid uzaklık ölçüsünden yararlanılmaktadır (Almeida, Barbosa, Pais \& Formosinho, 2007: 210). Daha sonra, nesnelerin gruplandırılması veya grupların çözülmesi adımı gelmektedir. Bu anlamda kullanılan en yaygın yaklaşım, tek nesnelerin gruplar halinde kademeli olarak birbirine bağlandığı toplayıcı tekniklerdir. İlk bağlantı zorunlu olarak en benzer nesne çiftine karşılık gelmektedir. Ardından ilk grup oluşturulduktan sonra, yeni grup ile kalan nesneler arasındaki benzerliği tanımlamak gerekmektedir. Bu adım, mevcut çeşitli teknikler arasında yeni bir seçim gerektirmektedir. En çok kullanılan bağlantı tekniklerinden bazıları tam bağlantı (veya en uzak komşu), tek bağlantı (veya en yakın komşu), ortalama bağlantı (gruplar arasında ve gruplar arasında) ve Ward bağlantı tekniğidir (Downs \& Barnard, 2002: 22-23; Smolinski, Walczak \& Einax, 2002: 46).

Çalışmanın bu bölümünde yararlanılan Hiyerarşik Kümeleme algoritmalarından Ward, Tam Bağlantı ve Tek Bağlantı tekniklerine detaylı olarak yer verilecektir.

\section{Ward Bağlantı Tekniğine Göre Kümeleme Analizi}

1963 yılında geliştirilen Ward tekniği, iki kümenin kaynaşmasının hata kareler toplamı ölçütünün büyüklügüne dayanmaktadır. Ward tekniğinde her aşamadaki amaç, E tarafından verilen küme içi hata kareler toplamındaki artışı en aza indirmektir.

$$
\begin{aligned}
\mathrm{E} & =\sum_{m=1}^{g} \quad E_{m}, \\
E_{m} & =\sum_{l=1}^{n_{m}} \quad \sum_{k=1}^{p_{k}} \quad\left(x_{m l, k}-\bar{x}_{m, k}\right)^{2}
\end{aligned}
$$

$\overline{\mathrm{x}}_{\mathrm{m}, \mathrm{k}}=\left(1 / \mathrm{n}_{\mathrm{m}}\right) \sum_{l=1}^{n_{m}} x_{m l, k}$ formülasyonu k' inci kriter için m' inci kümenin ortalamasını hesaplarken kullanılmaktadır. m' inci kümede yer alan nesnenin $(1, \ldots ., \mathrm{g}), \mathrm{x}_{\mathrm{ml}, \mathrm{k}} \mathrm{k}$ ' inci kriterinin $(\mathrm{k}$ $=1, \ldots$, p) skorunu belirlemek için yukarıdaki Eşitlik 2' den yararlanılmaktadır. Buradaki artış, birleştirilen kümelerin ağırlık merkezleri arasındaki Kare Öklid mesafesiyle orantılıdır (Everitt, Landau, Leese \& Stahl, 2011: 77-78).

Ward yöntemi hem homojen hem de heterojen kümeler ile sonuçlanan bir füzyon kriteri kullandığından dolayı diğer hiyerarşik toplayıcı yöntemlerinden farklılık göstermektedir. Küme içerisindeki kriterler arasındaki en aza indirgemesiyle homojen; kümeler arasındaki mesafeleri en üste çıkararak heterojen bir yapı kazanmasını sağlamaktadır. Bu, iki kümenin birleştirilmesiyle kümelenmiş toplam hataların küme içi toplamındaki artışın, birleştirilen iki kümenin ortalama merkezleri arasındaki kare Öklid mesafesiyle orantılı bir artışın en aza indirilmesiyle elde edilmektedir (Varin, Bureau, Mueller \& Willett, 2009: 188).

\section{Tam Bağlantı Tekniğine Göre Kümeleme Analizi}

İki küme arasındaki uzaklık, bir küme (k kümesi) ile başka bir kümenin (m kümesi) birbirlerine en uzak durumda bulunan iki elemanı arasındaki mesafe olarak ifade edilmektedir. Kümeler arası nesne çiftleri arasındaki maksimum uzaklık göz önünde bulundurulduğundan dolayı en uzak komşuluk tekniği olarak da adlandırılmaktadır (Murtagh \& Contreras, 2017: 5-6). Bir başka ifadeyle tam bağlantı tekniği, tek bağlantı tekniğinin çalışma prensibinin tam tersi şekilde işlem yapmaktadır. Aynı zamanda tam bağlantılı kümeleme tekniği tek bağlantılı kümeleme tekniklerine nazaran uç değerlere karşı daha az duyarlılık göstermektedir. Uzaklık ölçüsü $\mathrm{d}_{\mathrm{ij}}$ ile ifade edildiğinde, k kümesi ile m kümesinin birbirine en uzak olan iki değeri arasındaki uzaklık; 


$$
\mathrm{d}_{\mathrm{km}}=\max \left(\mathrm{d}_{\mathrm{pm}}, \mathrm{d}_{\mathrm{qm}}\right)
$$

Eşitlik 3'te gösterildiği gibi formülleştirilmektedir.

\section{Tek Bağlantı Tekniğine Göre Kümeleme Analizi}

Tek bağlantı tekniği ilk olarak Florek tarafından ortaya atılmıştır. Hiyerarşik kümeleme tekniklerinden en basit olanı tek bağlantı kümeleme tekniğidir. Bu teknikte bir küme ile diğer bir küme arasındaki mesafe minimumdur. Bir başka ifadeyle bir küme içerisinde yer alan bir nesne ile diğer bir küme içerisinde bulunan başka bir nesne arasındaki mesafenin minimum olması istenmektedir. Fakat tam bağlantı tekniğinde bu mesafelerin maksimum olması istenmektedir. Tek bağlantı tekniğinin tam bağlantı tekniğine göre daha sıklıkla tercih edilmesinin nedenlerinden bir tanesidir (Hartigan, 1981: 390; Fisher \& Van Ness, 1971: 93).

Tek bağlantı tekniğinde her adımda $\mathrm{p}$ kümesi ile q kümesinin bir araya getirilmesinin ardından meydana gelen yeni küme (k kümesi) ile diğer bir küme (m kümesi) arasındaki benzerlik şu şekilde ifade edilmektedir: Uzaklık ölçüsü $\mathrm{d}_{\mathrm{ij}}$ ile ifade edildiğinde, $\mathrm{k}$ kümesi ile $\mathrm{m}$ kümesinin birbirine minimum olan iki değeri arasındaki mesafe;

$$
\mathrm{d}_{\mathrm{km}}=\min \left(\mathrm{d}_{\mathrm{pm}}, \mathrm{d}_{\mathrm{qm}}\right)
$$

Eşitlik 4' teki gibidir. k kümesi ile m kümesi bir araya getirildiğinde, ortaya çıkan kümedeki bir değerin en yakın komşusuna olan uzaklığı en fazla $d_{k m}$ kadar olacaktır.

Tek bağlantı tekniğinin sağladığı en önemli fayda benzerlik matrisinin monoton dönüştürmelere karş1 değişken olmaması ve veri kümesindeki bağlı değerlerden etkilenmemesidir. Bu teknik birbirinden olabildiğince ayrık olan kümeleri saptamada oldukça kullanışlıdır. Tek bağlantı tekniği ile meydana getirilen kümedeki değerler, başka kümedeki değerlere göre birbirine daha çok benzemektedir (Y1lmaz \& Temurlenk, 2005: 82).

\section{Bulgular}

Yapılan bu çalışmada kümeleme analizinden yararlanılarak kripto paraların kümelenmesi üzerine bir uygulama yapılmışır. Çalışmada benzer kriterlere sahip kripto paraların kümelenmesi sonucu, yatırımcılara karar verme sürecinde yardımcı olunması amaçlanmıştır.

Kümeleme analizine dahil edilmek üzere piyasa değeri bakımından ilk 20 sırada yer alan kripto para tespit edilmiş, verileri tam olan 17 kripto para ile çalışma sınırlandırılmıştır. Bazı değişkenler için çok uzun bir zaman serilerine ulaşılabilirken, bir kısmı için daha dar tarih aralığına ilişkin verilere ulaşılabilmiştir. Analize dahil edilen tüm kripto paralar ve değişkenler için eksiksiz veri seti oluşturulabilen Haziran 2019 ile Nisan 2020 dönemi çalışmanın zaman aralığını oluşturmuştur. Çalışma Tüm Veri, Covid-19 öncesi ve Covid-19 sonrası olmak üzere üç farklı zaman diliminde ele alınmıştır. Bu sayede güncel gelişmelerin kripto paralar üzerinde etkili olup olmadığ1 da değerlendirilmiştir.

Çalışmada yararlanılan kümeleme analizi için Waikato Üniversitesi tarafindan üretilen WEKA programından yararlanılmıştır. Kümeleme analizi için WEKA programında yer alan ve finans çalışmalarında sıklıkla kullanılan hiyerarşik kümeleme tekniklerinden Ward, Tam Bağlantı ve Tek Bağlantı kümeleme teknikleri kullanılmıştır. 


\section{Ward Bağlantı Tekniğine Göre Kümeleme Analizi}

Yapılan bu çalışmada ilk olarak karar matrisi oluşturulmuştur. Oluşturulan bu matris, arff formatına çevrilmesinin ardından WEKA programına yüklenmiştir. Verilerin yer aldığg 1 WEKA ara yüzü Şekil 2'de gösterilmiştir.

Şekil 2: Verilerin Düzenlendiği WEKA Arayüzü

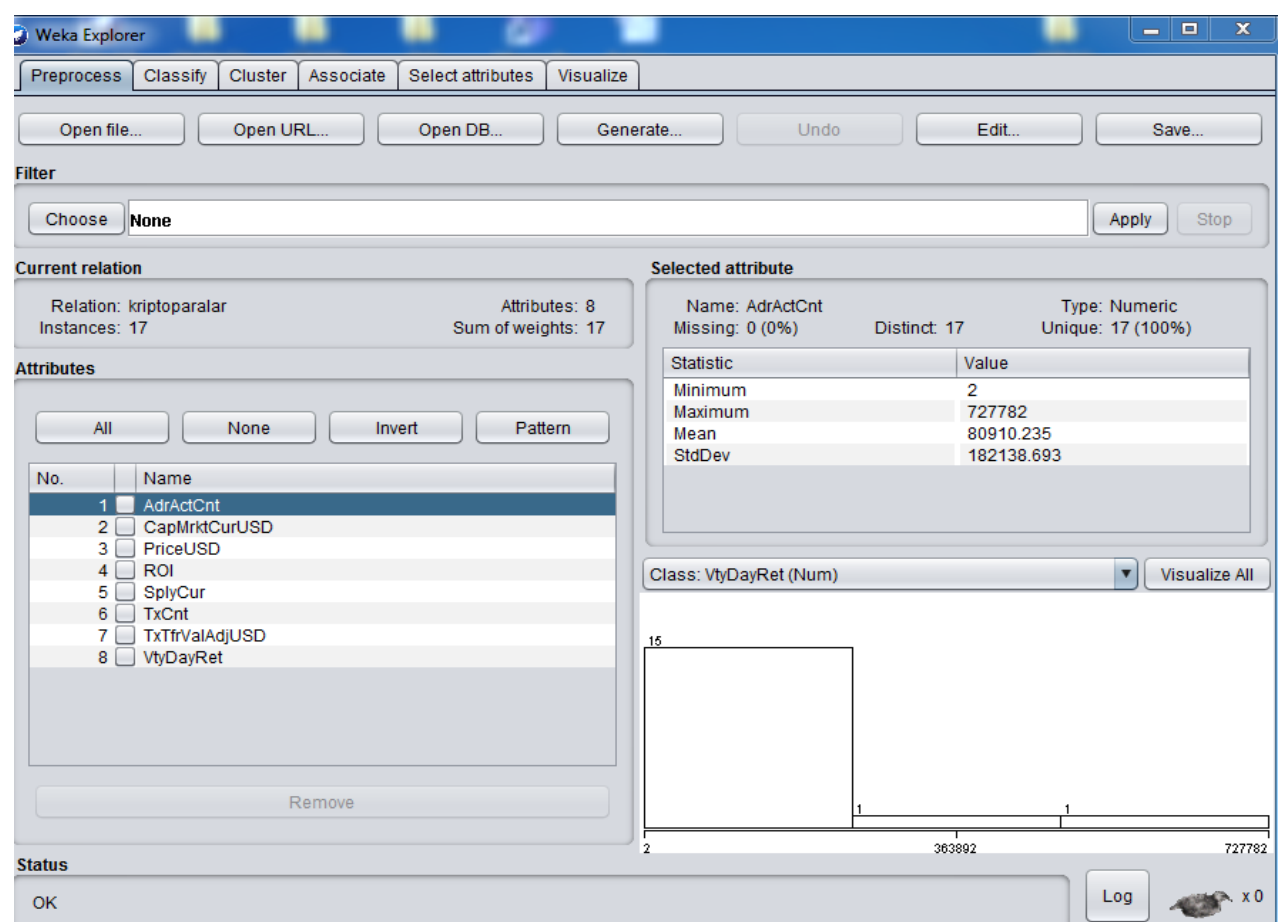

Şekil 2' de yer alan ekranda "Current Relation" başlığı altında çalışmada yararlanılan kriterler ve kriterlere ait bazı değerler sunulmuştur. Şekilde "AdtActCnt" kriteriyle ilgili ayrıntılara yer verilmiştir. 
Şekil 3: WEKA Küme Sayısı Belirleme Arayüzü

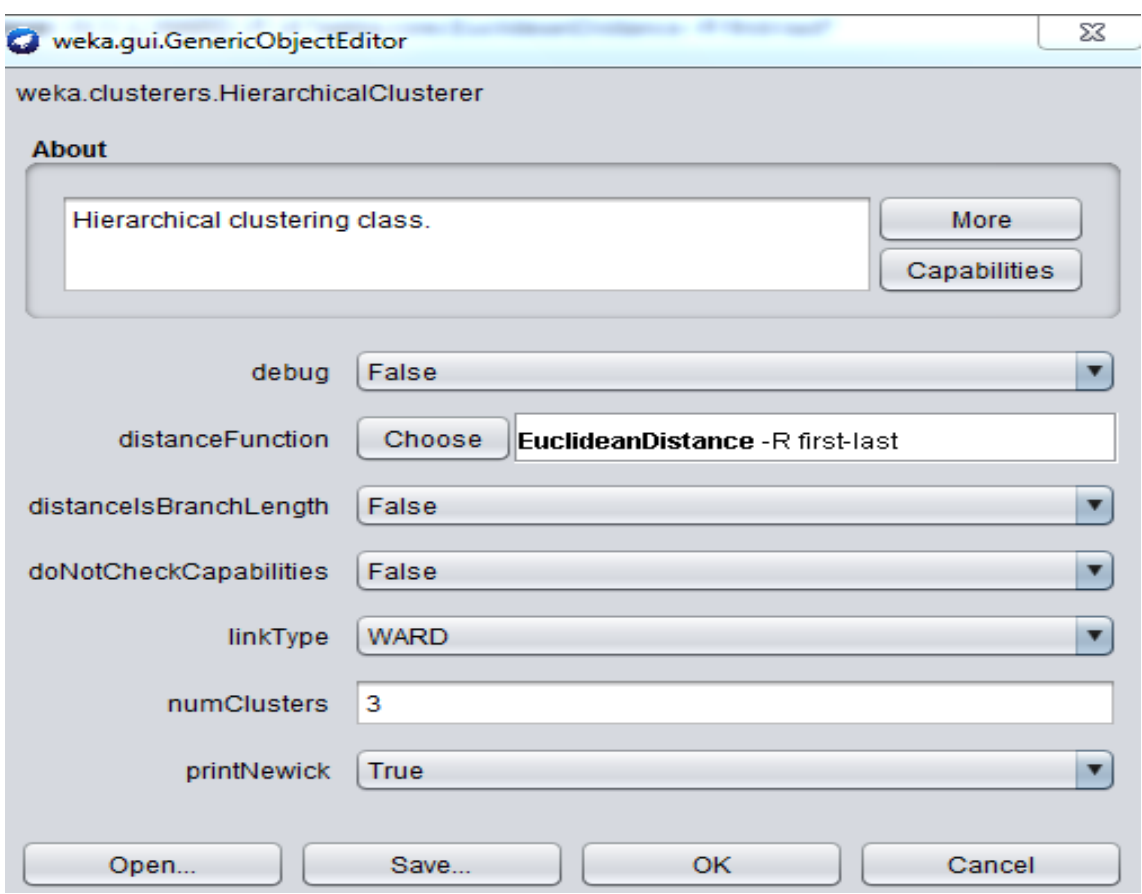

Küme sayısının saptanmasında literatürde kullanılan birçok formül bulunmaktadır. $\mathrm{Bu}$ çalışmada çoğunlukla kullanılan;

$$
k=\sqrt{\frac{n}{2}}
$$

Eşitlik 5’ten faydalanılmıştır (Çakmak, vd., 2005: 8). Bu çalışmada $k=\sqrt{\frac{17}{2}}$ eşitliğinin neticesinde çalışmada kullanılacak küme sayısı 3 olarak belirlenmiştir.

Şekil 4: WEKA Sonuç Arayüzü

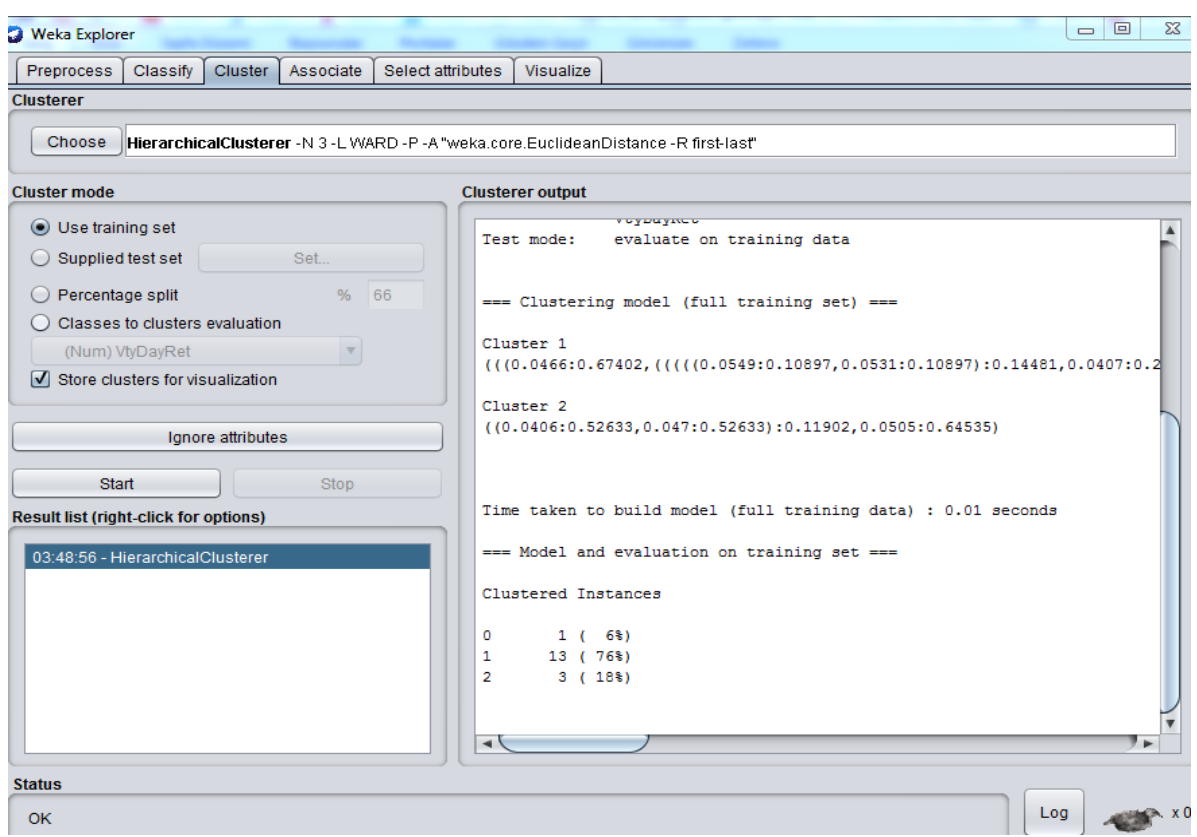

Turkish Studies - Economy, 15(3) 
Şekil 4'te WEKA sonuç arayüzü görülmektedir. Küme 0'a 1, Küme l'e 13 ve Küme 2 'ye 3 kripto paranın atandığı görülmektedir.

Ward tekniği kullanılarak yapılan kümeleme analizi sonucunda oluşan kümeler Tablo 4'te görülmektedir.

Tablo 4: Ward Tekniğine Göre Kripto Paraların Kümeleme Analizi Sonuçları

\begin{tabular}{|c|c|c|c|}
\hline & Tüm Veri Seti & Covid-19 Öncesi & Covid-19 Sonrası \\
\hline Küme 0 & Bitcoin & Bitcoin & Bitcoin \\
\hline \multirow{13}{*}{ Küme 1} & Ethereum & Ethereum & Ethereum \\
\hline & Tether & Tether & Tether \\
\hline & Bitcoin Cash & Bitcoin Cash & Bitcoin Cash \\
\hline & Bitcoin SV & Bitcoin SV & Bitcoin SV \\
\hline & Litecoin & Litecoin & Litecoin \\
\hline & Binance Coin & Binance Coin & Binance Coin \\
\hline & Tezos & Tezos & Tezos \\
\hline & Unus Sed Leo & Unus Sed Leo & Unus Sed Leo \\
\hline & Cardano & Cardano & Cardano \\
\hline & Chainlink & Chainlink & Chainlink \\
\hline & Huobi Token & Huobi Token & Huobi Token \\
\hline & USD Coin & USD Coin & USD Coin \\
\hline & Dash & Dash & Dash \\
\hline \multirow[t]{3}{*}{ Küme 2} & XRP & XRP & XRP \\
\hline & Stellar & Stellar & Stellar \\
\hline & Crypto.com Coin & Crypto.com Coin & Crypto.com Coin \\
\hline
\end{tabular}

Tablo 4'e bakıldığında Ward tekniği kullanılarak yapılan kümeleme işleminin sonucunda Tüm Veri, Covid-19 öncesi ve Covid-19 sonrası olmak üzere üç zaman aralığında da kümeler aynı kripto paralardan oluşmuştur.

\section{Tam Bağlantı Tekniğine Göre Kümeleme Analizi}

Tam Bağlantı tekniğine göre yapılan kümeleme analizi neticesinde oluşan kümeler Tablo 5 'te görüldüğü gibidir.

Tablo 5: Tam Bağlantı Tekniğine Göre Kripto Paraların Kümeleme Analizi Sonuçları

\begin{tabular}{|c|c|c|c|}
\hline \multirow{4}{*}{ Küme 0 } & Tüm Veri Seti & Covid-19 Öncesi & Covid-19 Sonras \\
\hline \multirow{4}{*}{} & Bitcoin & Bitcoin & Bitcoin \\
\cline { 2 - 4 } & Ethereum & Ethereum & Ethereum \\
\cline { 2 - 4 } & Tether & Tether & Tether \\
\cline { 2 - 4 } & Bitcoin Cash & Bitcoin Cash & Bitcoin Cash \\
\cline { 2 - 4 } & Bitcoin SV & Bitcoin SV & Bitcoin SV \\
\cline { 2 - 4 } & Litecoin & Litecoin & Litecoin \\
\cline { 2 - 4 } & Binance Coin & Binance Coin & Tezos Coin \\
\cline { 2 - 4 } & Tezos & Tezos & Unus Sed Leo \\
\cline { 2 - 4 } & Unus Sed Leo & Unus Sed Leo & Chainlink \\
\cline { 2 - 4 } & Cardano & Cardano & Huobi Token \\
\cline { 2 - 4 } & Chainlink & Chainlink & USD Coin \\
\cline { 2 - 4 } & Huobi Token & Huobi Token & Dash \\
\cline { 2 - 4 } & USD Coin & USD Coin & XRP \\
\hline \multirow{4}{*}{ Küme } & Dash & Dash & Stellar \\
\cline { 2 - 4 } & XRP & XRP & Crypto.com Coin \\
\hline
\end{tabular}


Tablo 5'e bakıldığında Tam Bağlantı tekniği kullanılarak yapılan kümeleme işleminin sonucunda Tüm Veri, Covid-19 öncesi ve Covid-19 sonrası olmak üzere üç zaman aralığında da kümeler aynı kripto paralardan oluşmuştur. Bu sonuçlar Ward tekniği sonuçları ile birebir aynıdır.

\section{Tek Bağlantı Kümeleme Tekniğine Göre Kümeleme Analizi}

Tek Bağlantı tekniğine göre yapılan kümeleme analizi neticesinde oluşan kümeler Tablo 6' da sunulmuştur.

Tablo 6: Tek Bağlantı Tekniğine Göre Kripto Paraların Kümeleme Analizi Sonuçları

\begin{tabular}{|c|c|c|c|}
\hline & Tüm Veri Seti & Covid-19 Öncesi & Covid-19 Sonrası \\
\hline Küme 0 & Bitcoin & Bitcoin & Bitcoin \\
\hline \multirow{15}{*}{ Küme 1} & Ethereum & Ethereum & Ethereum \\
\hline & Tether & Tether & Tether \\
\hline & Bitcoin Cash & Bitcoin Cash & Bitcoin Cash \\
\hline & Bitcoin SV & Bitcoin SV & Bitcoin SV \\
\hline & Litecoin & Litecoin & Litecoin \\
\hline & Binance Coin & Binance Coin & Binance Coin \\
\hline & Tezos & Tezos & Tezos \\
\hline & Unus Sed Leo & Unus Sed Leo & Unus Sed Leo \\
\hline & Cardano & Cardano & Cardano \\
\hline & Chainlink & Chainlink & Chainlink \\
\hline & Huobi Token & Huobi Token & Huobi Token \\
\hline & USD Coin & USD Coin & USD Coin \\
\hline & Dash & Dash & Dash \\
\hline & & Stellar & Crypto.com Coin \\
\hline & & Crypto.com Coin & \\
\hline \multirow{3}{*}{ Küme 2} & XRP & XRP & XRP \\
\hline & Stellar & & Stellar \\
\hline & Crypto.com Coin & & \\
\hline
\end{tabular}

Tablo 6'ya bakıldığında Tek Bağlantı Tekniği'nden yararlanılarak yapılan kümeleme işleminin sonucunda, Tüm Veri, Covid-19 öncesi ve Covid-19 sonrası olmak üzere üç zaman aralığında da Küme 0'da Bitcoin ortak durumdadır. Küme 1'de Ethereum, Tether, Bitcoin Cash, Bitcoin SV, Litecoin, Binance Coin, Tezos, Unus Sed Leo, Cardano, Chainlink, Huobi Token, USD Coin ve Dash, Küme 2'de ise XRP ortak durumdadır.

\section{Sonuc}

$\mathrm{Bu}$ çalışma ile piyasa değeri bakımından en büyük 17 kripto para belirlenen kriterler çerçevesinde kümelenmiştir. Çalışmada kripto paralar; tüm veri, Covid-19 öncesi ve Covid-19 sonrası olmak üzere üç farklı zaman diliminde ele alınmış olup hiyerarşik kümeleme analizi tekniklerinden Ward, Tam Bağlantı ve Tek Bağlantı teknikleriyle analiz edilmiştir. Kümeleme gerçekleştirilirken kripto paraların adres sayıları, piyasa değerleri, fiyatları, getirileri, arz miktarı, işlem sayısı, işlem hacmi ve volatiliteleri kullanılmıştır. Weka programı ile Ward ve tam bağlantı tekniğiyle yapılan analizlere bakıldığında Küme 0 , Küme 1 ve Küme 2'de yer alan tüm kripto paralar ele alınan üç farklı dönemde de aynı küme içerisinde bulunmaktadır. Tek bağlantı tekniği ile yapılan analiz sonuçlarına bakıldığında; diğer iki teknikten bazı farklılıklar gösterdiği görülmektedir. Ward Tekniği ve Tam Bağlantı Tekniği' ne göre, Covid-19 öncesi ve sonrası kripto paraların benzer özelliklere sahip oldukları dolayısıyla kümeleme sonuçlarının aynı olduğu görülmüştür. Tek Bağlantı Tekniği tüm veri setinde, yine Ward ve Tam Bağlantı teknikleriyle elde edilen sonuçla birebir aynı 
kümeleme oluşmuştur. Fakat Covid-19 öncesi dönemde kripto paralardan Crypto.com Coin ve Stellar farklı kümede yer almıştır. Yine Covid-19 sonrası dönemde yalnızca Crypto.com Coin diğer kriterlerin kümelemesinden farklı bir kümede yer almıştır.

Kripto para piyasası pazar büyüklüğü son yıllarda dikkate değer bir oranda büyüme göstermiştir. Piyasanın ulaştığı piyasa değeri 216 milyar dolara ulaşmıştır. Kripto para piyasasının \%64'ü Bitcoin'e aittir. 5400'e yakın kripto para içinden sadece 15'inin piyasa değeri bir milyar doların üzerinde yer almaktadır (CoinMarketCap, 2020). Bu açıdan değerlendirildiğinde, çalışmamızda kullanılan kümeleme analizinin sonucunda da Bitcoin ayrı kümelenmiştir. Üç tekniğe göre kümele sonucunda da benzer sonuçların ortaya çıkmıș olması çalıșma kapsamında kullanılan kümeleme tekniklerinin uygulanabilirliğinin göstergesi olarak bu çalıșmanın önemli sonuçlarından biridir. Her ne kadar Bitcoin piyasanın en önemli yatırım aracı olsa da, diğer kripto paralar da önemli bir piyasa büyüklüğüne ulaşmıştır. Dolayısıyla bu paralar da tanınmalı, piyasa ile ilgili bilgi karmaşıklığı mümkün olduğunca azaltılmalıdır. Çalışmanın bu açıdan yatırımcılara ve piyasayı tanımak isteyen ilgililere yardımda bulunabileceği düşünülmektedir. Sonuç olarak çalışmada benzer özellikler gösteren kripto paralar kümelenmiş ve yatırımcılara karar verme aşamasında yardımcı olabilecek makro bilgiler sunulmuştur. Araştırmanın sonucuna göre Bitcoin, altcoinlerden ayrışarak ayrı bir küme oluşturmuştur. Bu sonuç Song vd.'nin (2019) araştırması ile benzerlik göstermektedir.

$\mathrm{Bu}$ çalışma piyasa değeri bakımından ilk 17 sırada yer alan kripto paralar alternatif olarak seçilmiştir. Bundan sonra yapılacak olan çalışmalarda alternatif sayısı artırılarak kümeleme çalışması yapılabilir. Ayrıca bu çalışmada analiz kısmında hiyerarşik kümeleme analizi tekniklerinden yararlanılmıştır. Yapılacak diğer çalışmalarda araştırmacılar farklı teknikleri tercih edilebilir.

\section{Kaynakça}

Adjepong, M. O. \& Alagidede, I. P. (2019). Multiresolution analysis and spillovers of major cryptocurrency markets. Research in International Business and Finance, 49, 191-206.

Akçalı, B. Y. \& Şişmanoğlu, E. (2019). Kripto para birimleri arasındaki ilişkinin Toda-Yamamoto nedensellik testi ile analizi. Ekev Akademi Dergisi, 23(78), 99-122.

Arsov, A. (2018). Periodic table of cryptocurrencies: blockchain categorization. SSRN Electronic Journal, 1-20.

Akın, Y. K. (2008). Veri madenciliğinde kümeleme algoritmalarl ve kümeleme analizi. Yayınlanmamış doktora tezi, Marmara Üniversitesi Sosyal Bilimler Enstitüsü.

Albayrak, A. \& Yılmaz, Ş.K. (2009). Veri madenciliği: karar ağaçları ve İMKB verileri üzerine bir uygulama. Süleyman Demirel Üniversitesi İktisadi ve İdari Bilimler Fakültesi Dergisi, 14(1), 31-52.

Almeida, J. A. S., Barbosa, L. M. S., Pais, A. A. C. C. \& Fornosinho, S. J. (2007). Improving hierarchical cluster analysis: a new method with outlier detection and automatic clustering. Chemometrics and Intelligent Laboratory Systems, 87, 208-217.

Arı, E. S., Özköse, H., Doğan, A. \& Calp, M. H. (2016). İstanbul Borsası'nda işlem gören firmaların finansal performanslarının kümeleme analizi ile değerlendirilmesi. Bilişsim Teknolojileri Dergisi, 9(1), 33.39.

Avrupa Merkez Bankas1, (2012). Virtual currency schemes.

Baig, A., Blau, B. M. \& Sabah, N. (2019). Price clustering and sentiment in bitcoin. Finance Research Letters, 29, 111-116. 
Baig, A. S. \& Sabah, N. (2019). Does short selling affect the clustering of stock prices?, The Quarterly Review of Economics and Finance, 1-8.

Blau, B. M. \& Griffith, T. G. (2016). Price clustering and the stability of stock prices. Journal of Business Research, 69, 3933-3942.

Bouri, E., Shahzad, S. J. H. \& Roubaud, D. (2019). Co-explosivity in the cryptocurrency market. Finance Research Letters, 29, 178-183.

Ciaian, P., Rajcaniova, M. \& Kancsa, A. (2018). Virtual relationships: short-and long-run evidence from bitcoin and altcoin markets. Journal of International Financial Markets, Institutions and Money, 52, 173-195.

Çakmak, Z., Uzgören, N. \& Keçek, G. (2005). Kümeleme analizi teknikleri ile illerin kültürel yapılarına göre sınıflandırılması ve değişimlerinin incelenmesi. Dumlupınar Üniversitesi Sosyal Bilimler Dergisi, 1-21.

Çalış, A. \& Baynal, K. (2016). Kümeleme analizi ile bankacıllk sektöründe satış stratejilerinin belirlenmesi. Beykent Üniversitesi Fen ve Mühendislik Bilimleri Dergisi, 9(1), 13-41.

Downs, G.M. \& Barnard, J.M. (2002). Clustering methods and their uses in computational chemistry, in: K.B. Lipkowitz, D.B. Boyd (Eds.). Reviews in Computational Chemistry, Vol: 18, Wiley, United Kingdom, 1-40.

Everitt, B. S., Landau, S., Leese, M. \& Stahl, D. (2011). Cluster analysis $5^{\text {th }}$ edt, A John Wiley and Sons, Publication.

Farell, R. (2015). An analysis of the cryptocurrency industry. Wharton Research Scholars.

Fisher, L. \& Ness, J. W. (1971). Admissible clustering procedures. Biometrika, 58, 91-104.

Gazel, S. \& Akel, V. (2018). Borsa İstanbul' da sektör sınıflandırmasının kümeleme analizi ile belirlenmesi. Muhasebe ve Finansman Dergisi, Ocak, 147-164.

Hartigan, J. (1981). Consistency of single linkage for high-density clusters. Journal of The American Statistical Assocation, 76, 388-394.

Hu, B., McInish, T., Miller, J. \& Zeng, L. (2019). Intraday price behavior of cryptocurrencies. Finance Research Letters, 28, 337-342.

Kalfa, V. R. \& Bekçioğlu, S. (2013). İMKB'de işlem gören gıda, tekstil ve çimento sektörü şirketlerinin finansal oranlar yardımıyla kümelenmesi. Dumlupınar Üniversitesi Sosyal Bilimler Dergisi, EYİ 2013 Özel Sayıs1, 441-464.

Karaağaç, G. A. \& Altınırmak, S. (2018). En yüksek piyasa değerine sahip on kripto paranın birbirleriyle etkileşimi. Muhasebe ve Finansman Dergisi, 79, 123-138.

Karabayır, M. E. \& Doğanay, M. (2010). Kümeleme analizi ile portföy seçimi: İMKB-100 endeksi üzerine bir çalışma. Ticaret ve Turizm Eğitim Fakültesi Dergisi, 2, 160-179.

Ketchen, D. \& Shook, C. L. (1996). The application of cluster analysis in strategic management research: an analysis and critique. Strategic Management Journal, 17(6), 441-458.

Konuşkan, A., Teker, T., Ömürbek, V. \& Bekci, İ. (2019). Kripto paraların fiyatları arasındaki ilişsinin tespitine yönelik bir araştırma. Süleyman Demirel Üniversitesi İktisadi ve İdari Bilimler Fakültesi Dergisi, 24(2), 311-318.

Koyuncugil, A. S. \& Özgülbaş, N. (2006). İMKB' de işlem gören KOBİ' lerin finansal başarısızlığına etki eden faktörlerin veri madenciliği ile belirlenmesi. 3. KOBİ ve Verimlilik Kongresi, 17-18 Kasım. 
Mishra, A. K. \& Tripathy, T. (2018). Price and trade size clustering: evidence from the national stock exchange of India. The Quarterly Review of Economics and Finance, 68, 63-72.

Murtagh, F. \& Contreras, P. (2017). Algorithms for hierarchical clustering: an overview II. WIREs Data Mining and Knowledge Discovery, 7(6), 1-16.

Osterrieder, J., Lorenz, J. \& Strika, M. (2016). Bitcoin and cryptocurrencies-not for the faint-hearted. International Journal and Banking, 4(1), 56-94.

Sigaki, H. Y., Perc, M. \& Ribeiro, H. V. (2019). Clustering patterns in efficiency and the coming-ofage of the cryptocurrency market. Scientific reports, 9(1), 1-9.

Smoliński, A., Walczak, B. \& Einax, J.W. (2002). Hierarchical clustering extended with visual complements of environmental data set. Chemom. Intell. Lab. Syst. 64, 45-54.

Song, J. Y., Chang, W. \& Song, J. W. (2019). Cluster analysis on the structure of the cryptocurrency market via bitcoin-ethereum filtering. Physica A, 527, 1-16.

Steinbach, M., Ertoz, L. \& Kumar, V. (2003). Challenges of clustering in high dimensional data, University of Minnesota Supercomputing Institute Research Report, 213, 1-33.

Tekin, B. (2018). Ward, K-Ortalamalar ve İki Adımlı kümeleme analizi yöntemleri ile finansal göstergeler temelinde hisse senedi tercihi. Balıkesir Üniversitesi Sosyal Bilimler Enstitüsü Dergisi, 21(40), 401-436.

Urquhart, A. (2017). Price clustering in Bitcoin. Economics Letters, 159, 145-148.

Usta, A. \& Doğantekin, S. (2018). Blockchain 101. İstanbul: Bankalararası Kart Merkezi.

Varin, T., Bureau, R., Mueller, C. \& Willett, P. (2009). Clustering files of chemical structures using the Szekely-Rizzo generalization of Ward's method. Journal of Molecular Graphics and Modelling 28, 187-195.

Vatansever, M. (2008). Görsel veri madenciliği tekniklerinin kümeleme analizlerinde kullanımı ve uygulanması. Yayınlanmamıs yüksek lisans tezi, Yıldız Teknik Üniversitesi Fen Bilimler Enstitüsü.

Xin, L., Shenghong, L. \& Chong, X. (2020). Price clustering in bitcoin market-an extension. Finance Research Letters, 32, 1-9.

Yılmaz, Ö. \& Temurlenk, M. S. (2005). Türkiye' deki istatistik bölgelerin kişi başına düşen gelir açısından hiyerarşik ve hiyerarşik olmayan kümeleme analizi ile değerlendirilmesi: 19652001. Atatürk Üniversitesi İktisadi ve İdari Bilimler Fakültesi Dergisi, 19(2), 75-92.

(2020, Nisan 26). CoinMarketCap: https://coinmarketcap.com/rankings/exchanges/

(2020, Nisan 26). CoinMetrics: https://coinmetrics.io/community-network-data/

(2020, Nisan 7). CoinMetrics: https://coinmetrics.io/community-network-data/

(2020, Nisan 5). New York Times: https://www.nytimes.com/2020/01/10/world/asia/china-viruswuhan-death.html 